\title{
A Comparative Study on the Efficiency of CFRP and GFRP in the Improvement of Compressive Strength, Acoustic Impedance and Bracing of Filled and Hollow Concrete Columns in Different Layers and Ages
}

\author{
Mohammadreza Zarringol $^{1}$ \& ${\text { Mohammadehsan } \text { Zarringol }^{2}}^{2}$ \\ ${ }^{1}$ Civil Engineering Department, Sharif University of Technology, International Campus, Kish Island, Iran \\ ${ }^{2}$ Geotechnical Engineering Department, University of Guilan, Rasht, Iran \\ Correspondence: Mohammadreza Zarringol, Civil Engineering Department, Sharif University of Technology, \\ International Campus, Kish Island, Iran. Tel: 98-91-2118-7151. E-mail: Zarringol_reza@yahoo.com
}

Received: July 31, 2016 Accepted: August 25, 2016 Online Published: September 27, 2016

doi:10.5539/jsd.v9n5p110

URL: http://dx.doi.org/10.5539/jsd.v9n5p110

\begin{abstract}
FRP technique is growing in popularity as a modern strengthening method. When it comes to FRP, concrete surface strength plays a determining role in the bond between FRP and concrete. This paper aims to compare the efficiency of CFRP and GFRP in the improvement of compressive strength, acoustic impedance and bracing of filled and hollow concrete columns in different layers and ages. In doing so, we carried out various tests on 18 samples in the ages of 3, 7, 14, 28, 42 and 90 days. According to the results, the strength of un-braced carbon and glass increased by $19-40 \%$ and $8-43 \%$ respectively and the strength of braced carbon and glass increased by $17-25 \%$ and $10-82 \%$ respectively. The compressive strength increased by $66 \%$ in one-layer CFRP hollow column, $96 \%$ in two-layer CFRP hollow column, $123 \%$ in three-layer CFRP hollow column, $36 \%$ in one-layer GFRP hollow column, $63 \%$ in two-layer GFRP hollow column, 105\% in three-layer GFRP hollow column, 71\% in one-layer CFRP filled column, $138 \%$ in two-layer CFRP filled column, $154 \%$ in three-layer CFRP filled column, $45 \%$ in one-layer GFRP filled column, $79 \%$ in two-layer GFRP filled column, and $144 \%$ in three-layer GFRP filled column. The ultimate strength of the beams with flexural-shear strengthening was higher than other beams. Also, the increased percentage of fiber resulted in the increased speed of ultrasonic waves.
\end{abstract}

Keywords: GFRP, CFRP, FRP, flexural strength, shear strength, hollow column, filled column

\section{Introduction}

In the modern age, strengthening the main structural elements is crucially important because the restoration of deteriorated structures would impose huge cost. With the emergence of FRP materials and powerful epoxy resins, a modern strengthening method has been introduced in response to the growing need for repairing and strengthening steel and concrete structures [Klees, M. 2004; Arduini, M., \& Nanni, A. 1997; Barros, J. A., \& Sena-Cruz, J. 2002; Wambold, J. C., Henry, J. J., \& Hegmon, R. R. 1982; Abu-Tair, A. I., Lavery, D., Nadjai, A., Rigden, S. R., \& Ahmed, T. M. A. 2000]. FRP sheet may be adhered to tension side of concrete beam to provide additional reinforcement. This sheet increases beam performance under service loads, reduces the displacements and cracks, and increases ultimate flexural strength [Talbot, C., Pigeon, M., Beaupré, D., \& Morgan, D. R. (1995); Gao, B., Kim, J. K., \& Leung, C. K. (2004);

Ueda, T., \& Dai, J. (2005); Benyoucef, S., Tounsi, A., Bedia, E. A., \& Meftah, S. A. (2007); Kang, T. H. K., Howell, J., Kim, S., \& Lee, D. J. (2012)].

Since the early 1990s, a lot of studies have been done about the structural behavior of FRP-reinforced beams under ultimate conditions. These studies indicate that while composite materials can be successfully used during strengthening operations, some failures occur in the majority of such structures before reaching the ultimate capacity determined for the structure. Such failure, called premature failure, may limit the advantages of this method and lead to disastrous events [Naderi, M. (2011)]. There are three materials (FRP, glue and concrete) and two interfaces (FRP/glue and concrete/glue) in the bond between FRP and concrete. The failure may occur in the materials or in the interfaces. Seven failures have been identified in FRP-reinforced beams: FRP sheet fracture, concrete crushing under 
pressure, shear failure, concrete cover fracture, detachment of the end of FRP sheet at FRP-concrete interface, and development of flexural or flexural-shear crack at the middle of the beam [ASTM, C. (2005); Seo, S. Y., Feo, L., \& Hui, D. (2013); Yuan, H., Lu, X., Hui, D., \& Feo, L. (2012); Chen, D., \& El-Hacha, R. (2013); Correia, J. R., Branco, F. A., \& Ferreira, J. (2009); Neagoe, C. A., \& Gil, L. (2014)]. The most common types are concrete cover fracture and concrete-FRP interface detachment. Premature failures mainly start with the development of flexural and shear cracks. The detachment proceeds further due to concentration of stress at the end of FRP sheet or in the area between FRP sheet and flexural reinforcements inside the concrete [Sekijima, K., Ogisako, E., Miyata, K., \& Hayashi, K. (2001)]. These failures mainly occur due to concentration of shear and normal stresses of concrete-FRP interface at the points of FRP fracture and flexural cracks along the beam. Since the premature failure prevents an element from reaching its ultimate capacity and reduces ductility, it is essential to predict the ultimate load at the moment of premature failure [Mendes, P. J., Barros, J. A., Sena-Cruz, J. M., \& Taheri, M. (2011); Mutsuyoshi, H., Shiroki, K., Hai, N. D., \& Ishihama, T. (2011); Gonilha, J. A., Correia, J. R., \& Branco, F. A. (2014); Correia, J. R., Branco, F. A., \& Ferreira, J. G. (2007); Dalalbashi, A., Eslami, A., \& Ronagh, H. R. (2012); Belarbi, A. (2011)].

While researchers have suggested the use of bracing systems to prevent the detachment of FRP sheet and the use of furrowing methods (external reinforcement by longitudinal furrows, EBROG) to postpone the failure, such methods are not still used in structures [Saraswathy, M. T., \& Dhanalakshmi, M. K. (2014); Ronagh, H. R., \& Eslami, A. (2013); Sen, T., \& Reddy, H. J. (2013); Hamid, N. A. A., Thamrin, R., \& Ibrahim, A. (2013); El-Nemr, A., Ahmed, E. A., \& Benmokrane, B. (2013); Safan, M. A. (2013); Belarbi, A., \& Acun, B. (2013); Attari, N., Amziane, S., \& Chemrouk, M. (2012); Parikh, K., \& Modhera, C. D. (2012); El Maaddawy, T., Soudki, K., \& Topper, T. (2005)]. Furthermore, a considerable cost would be imposed if an optimal way is not determined for the use of FRP. The prediction of premature failure requires a good understanding of detachment process. Studies indicate that the strength of adhesive in FRP-concrete interface is one of the important factors in the behavior of reinforced structures. Therefore, a series of laboratorial studies have been done about the behavior of bond layer using a combination of tests such as shear tests, double shear tests and modified beams [Chen, G. M., Teng, J. G., \& Chen, J. F. (2012); Antonopoulos, C. P., \& Triantafillou, T. C. (2003); Chitsazan, I., Kobraei, M., Jumaat, M. Z., \& Shafigh, P. (2010); Tavares, D. H., Giongo, J. S., \& Paultre, P. (2008); Esfahani, M. R., Kianoush, M. R., \& Tajari, A. R. (2007); Barros, J. A., \& Fortes, A. S. (2005); Systèmes, D. (2011)]. In the recent years, some researchers have focused on adhesive layer modeling. They have defined the mechanical behavior of adhesive layer in a linear elastic form in order to simulate the behavior of FRP-concrete interface. The disadvantage of this method is the lack of a parameter for the failure of adhesive layer [Hu, H. T., Lin, F. M., \& Jan, Y. Y. (2004); Almusallam, T. H., \& Al-Salloum, Y. A. (2005); Pendhari, S. S., Kant, T., \& Desai, Y. M. (2008); Bakis, C. E., Ganjehlou, A., Kachlakev, D. I., Schupack, M., Balaguru, P. N., Gee, D. J., ... \& Kliger, H. S. (2002)]. This paper aims to compare the efficiency of CFRP and GFRP in the improvement of compressive strength, acoustic impedance and bracing of concrete filled and hollow columns in different layers and ages.

\section{Method}

First, we prepared the surface of element for FRP composite bonding. As the bond between FRP and element was vital to the final result, we exercised sufficient care in this step. Surface preparation included the removal of additional materials such as cement juice and chemicals from the surface and polishing the surface by a polisher so that the roughness reached below $1 \mathrm{~mm}$. Finally, FRP was mounted on beam surface in laboratorial temperature $\left(20^{\circ} \mathrm{C}\right)$ by epoxy resin.

Considering the limited laboratorial equipment, we selected a few beams with the length of $1.2 \mathrm{~m}$ and cross section of $10 \mathrm{~m}$ as our samples, in which a $\emptyset 10$ bar was used to strengthen the tensile part, a $1 \emptyset 8$ bar was used to strengthen the compressive part, and a $\emptyset 6$ reinforcement was used as collar. We continued loading with a fixed speed until beam destruction and recorded the results in the form of force-displacement curve. The displacement was measured using the strain gauge with the accuracy of 0.001 at the middle of the beam. FRP fabrics with the width of $10 \mathrm{~cm}$ and length of $90 \mathrm{~cm}$ were installed $5 \mathrm{~cm}$ away from the support. Before loading, the samples were kept in laboratorial environment for one week. The concrete had a compressive strength of $25 \mathrm{mpa}$ and the steel has a failure resistance of 400mpa. The elasticity modulus $\left(\mathrm{KN} / \mathrm{mm}^{2}\right)$ was 240 for carbon and 70 for glass. Thickness $(\mathrm{mm})$ was 175 for carbon and 17 for glass. Ultimate strain was 1.50 for carbon and 3.2 for glass. Tensile strength $\left(\mathrm{N} / \mathrm{mm}^{2}\right)$ was 3650 for carbon and 2280 for glass. Special weight $\left(\mathrm{g} / \mathrm{m}^{2}\right)$ was 290 for carbon and 425 for glass. All beams were designed in accordance with ABA standards and in compliance with minimum and maximum reinforcement in beam.

The beams were made by concrete mixture with water-to-cement ratio of 0.50 , using coarse aggregates with maximum grain size of $16 \mathrm{~mm}$ and sand with fineness modulus of 209 based on ASTM standard. After 24 hours, the beams were demolded and processed in water tank for 28 days. The non-reinforced beam, called R, was set as the reference sample. This sample was reinforced by only putting steel inside the beam. In order to study CFRP, we used 
three beams with 1-3 carbon layers with a thickness of $0.0165 \mathrm{~mm}$. For the purpose of GFRP, we used three beams with 1-3 glass fiber layers with a thickness of $0.0165 \mathrm{~mm}$. In addition to beams with unbraced ends, another group of beams were braced by glass fiber with the size of $15 * 25 \mathrm{~cm}$ in $u$ form. This group of beams are marked E (Table 1 ).

Hollow and filled columns were made by concrete mixture using Abadeh type 2 cement, washed sand and pea gravel with the strength of 20mpa. The small-sized cylindrical columns had the height of $30 \mathrm{~cm}$ and diameter of $15 \mathrm{~mm}$. All samples were processed in steam bath for 28 days. After the samples dried, we filled the corrosions by a special epoxy resin and leveled the surfaces of all samples. In each group of seven samples, one was set as control sample, three were wrapped in CFRP and three were wrapped in GFRP with one, two and three layers.

Ultrasonic wave test was carried out using Pandit device based on 83-597ASTM C on cubic samples in the ages of 3 , $7,14,28,42$ and 90 days. We performed this test to determine ultrasonic wave speed passing the concrete and depict compressive strength-wave speed correlation curve.

Table 1. Abbreviations of samples

\begin{tabular}{|c|c|c|}
\hline No & Symbol & Description \\
\hline 1 & $\mathrm{R}$ & Reference beam \\
\hline 2 & $\mathrm{C}_{-} \mathrm{L}_{1}$ & Single-layer CFRP cover \\
\hline 3 & $\mathrm{C}_{-} \mathrm{L}_{2}$ & Two-layer CFRP cover \\
\hline 4 & $\mathrm{C}_{-} \mathrm{L}_{3}$ & Three-layer CFRP cover \\
\hline 5 & $\mathrm{G} \__{-} \mathrm{L}_{1}$ & Single-layer GFRP cover \\
\hline 6 & G_L $L_{2}$ & Two-layer GFRP cover \\
\hline 7 & G_L $L_{3}$ & Three-layer GFRP cover \\
\hline 8 & $\mathrm{C}_{-} \mathrm{L}_{1} \_\mathrm{E}$ & Single-layer CFRP cover with end brace \\
\hline 9 & $\mathrm{C}_{-} \mathrm{L}_{2} \_\mathrm{E}$ & Two-layer CFRP cover with end brace \\
\hline 10 & $\mathrm{C}_{-} \mathrm{L}_{3} \mathrm{E}$ & Three-layer CFRP cover with end brace \\
\hline 11 & $\mathrm{G}_{-} \mathrm{L}_{1} \_\mathrm{E}$ & Single-layer GFRP cover with end brace \\
\hline 12 & $\mathrm{G}_{-} \mathrm{L}_{2} \mathrm{E}$ & Two-layer GFRP cover with end brace \\
\hline 13 & $\mathrm{G}_{-} \mathrm{L}_{3} \mathrm{E}_{\mathrm{B}}$ & Three-layer GFRP cover with end brace \\
\hline 14 & $\mathrm{C}_{-} \mathrm{L}_{1_{-}} \mathrm{EM}$ & Single-layer CFRP cover - hollow column \\
\hline 15 & $\mathrm{C}_{-} \mathrm{L}_{2} \mathrm{EM}$ & Two-layer CFRP cover - hollow column \\
\hline 16 & $\mathrm{C}_{-} \mathrm{L}_{3} \mathrm{EM}$ & Three-layer CFRP cover - hollow column \\
\hline 17 & $\mathrm{G}_{-} \mathrm{L}_{1} \mathrm{EM}$ & Single-layer GFRP cover - hollow column \\
\hline 18 & $\mathrm{G}_{-} \mathrm{L}_{2} \mathrm{EM}$ & Two-layer GFRP cover - hollow column \\
\hline 19 & $\mathrm{G}_{-} \mathrm{L}_{3} \mathrm{EM}$ & Three-layer GFRP cover - hollow column \\
\hline 20 & $\mathrm{C}_{-} \mathrm{L}_{1} \mathrm{FF}$ & Single-layer CFRP cover - filled column \\
\hline 21 & $\mathrm{C}_{-} \mathrm{L}_{2} \mathrm{FF}$ & Two-layer CFRP cover - filled column \\
\hline 22 & $\mathrm{C}_{-} \mathrm{L}_{3} \mathrm{FF}$ & Three-layer CFRP cover - filled column \\
\hline 23 & $\mathrm{G}_{-} \mathrm{L}_{1} \mathrm{FF}$ & Single-layer GFRP cover - filled column \\
\hline 24 & $\mathrm{G}_{-} \mathrm{L}_{2} \mathrm{FF}$ & Two-layer GFRP cover - filled column \\
\hline 25 & $\mathrm{G}_{-} \mathrm{L}_{3} \mathrm{FF}$ & Three-layer GFRP cover - filled column \\
\hline
\end{tabular}

\section{Results}

We used two strain gauges at the middle of the beam and force point to investigate the flexural behavior of the beam. The displacement at each of these points was measured using strain gauges with accuracy of 0.001 in and the behavior of other beams was evaluated in comparison with the reference beam. Figure 1-3 illustrates the flexural strength, Percentage of increased flexural strength and Ultimate creep of reinforced samples compared to the 
reference beam.
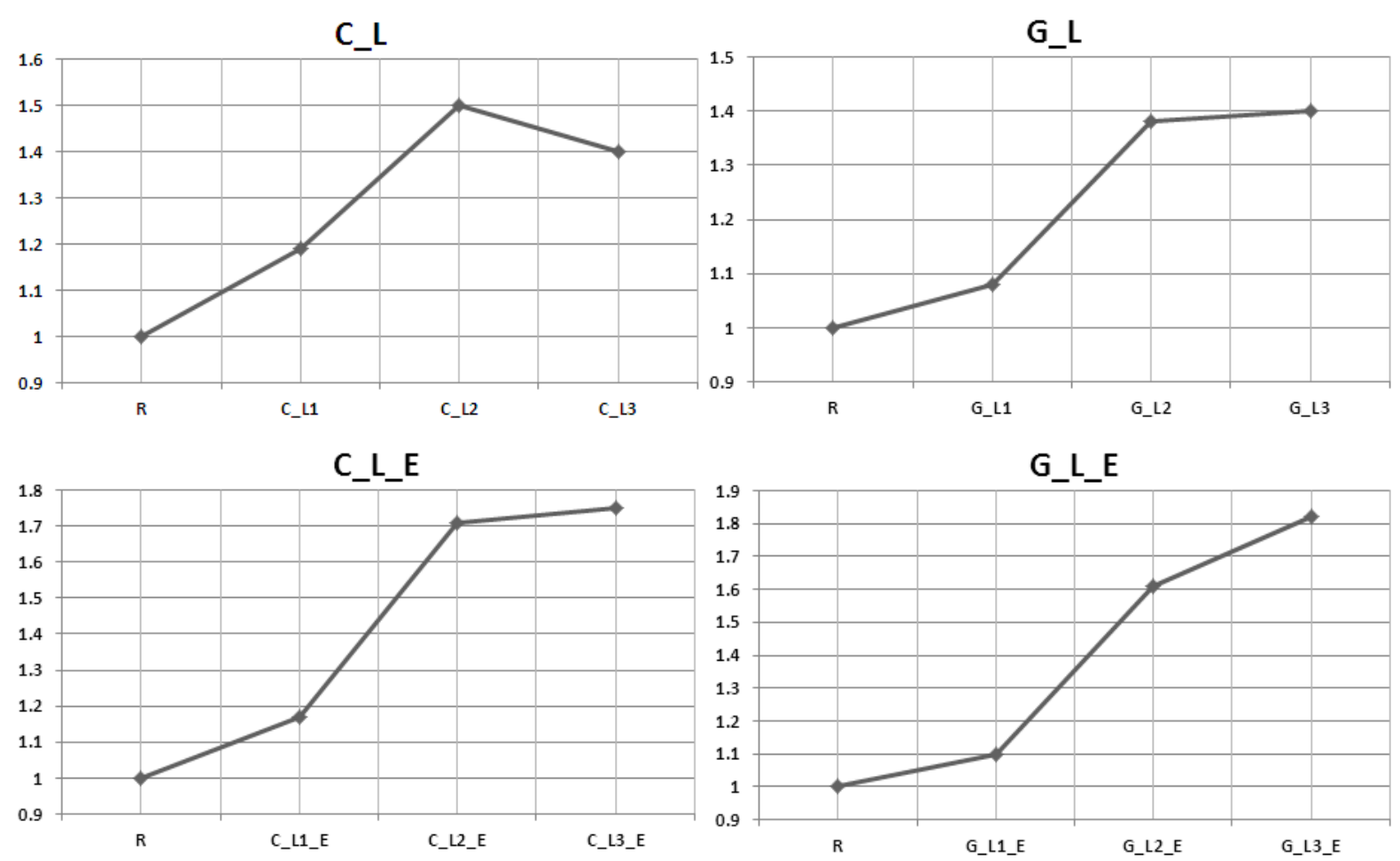

Figure 1. Flexural Strength

C_L

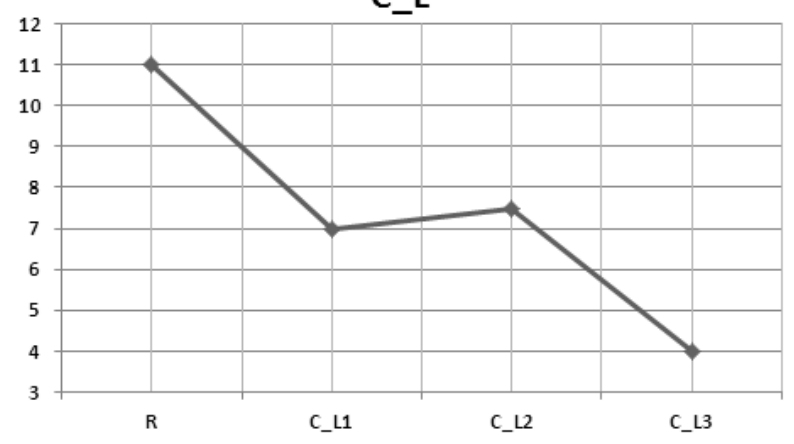

C_L_E

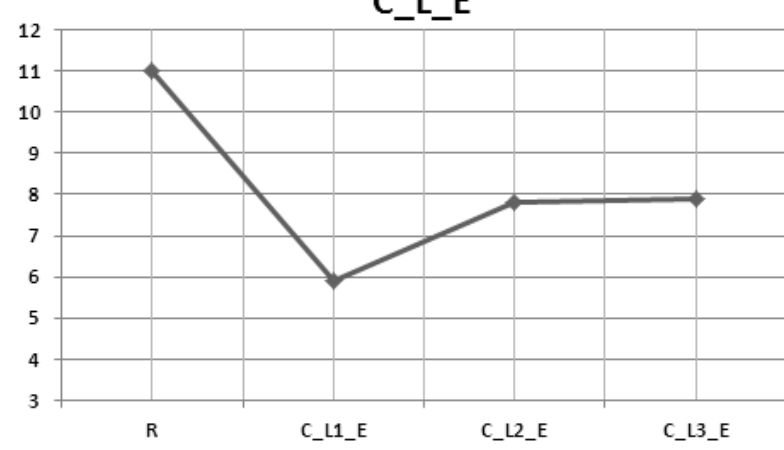

G_L

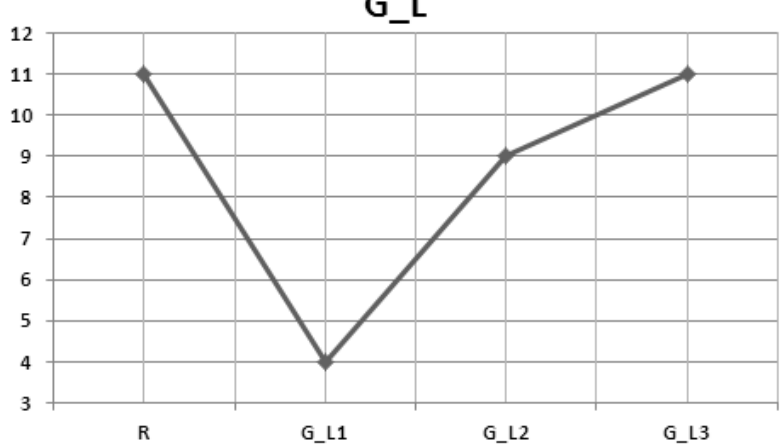

G_L_E

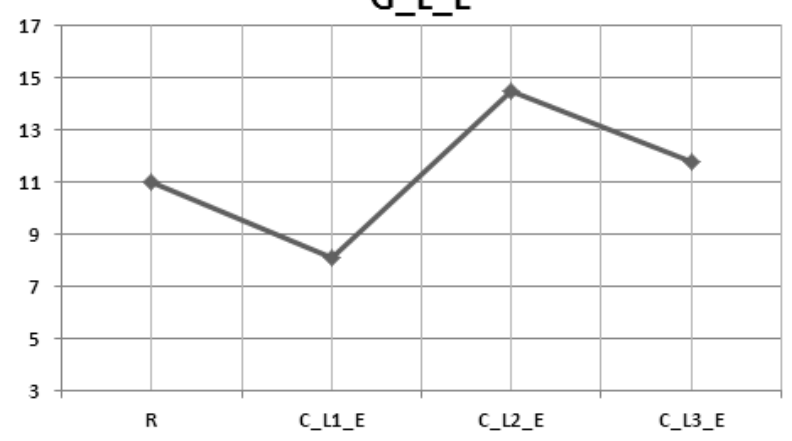

Figure 2. Ultimate creep 
C_L

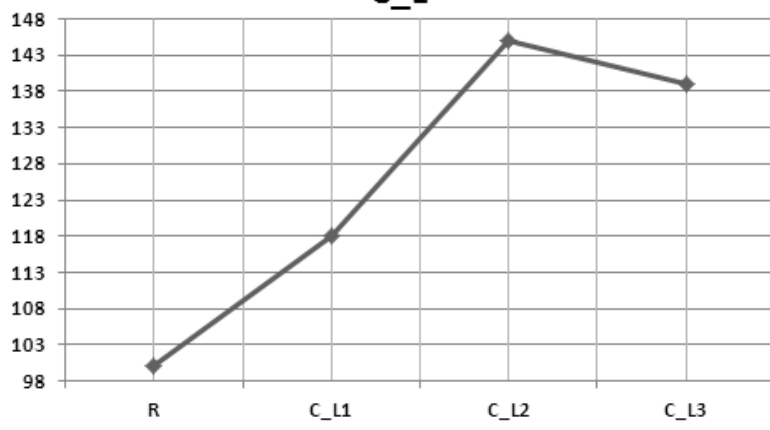

C_L_E

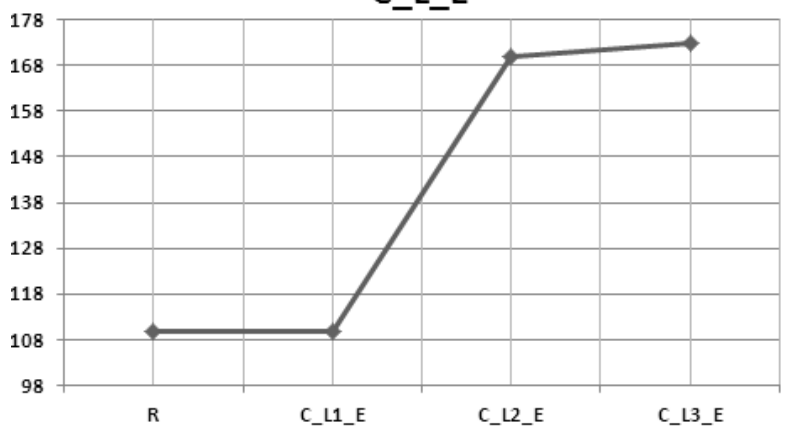

G_L

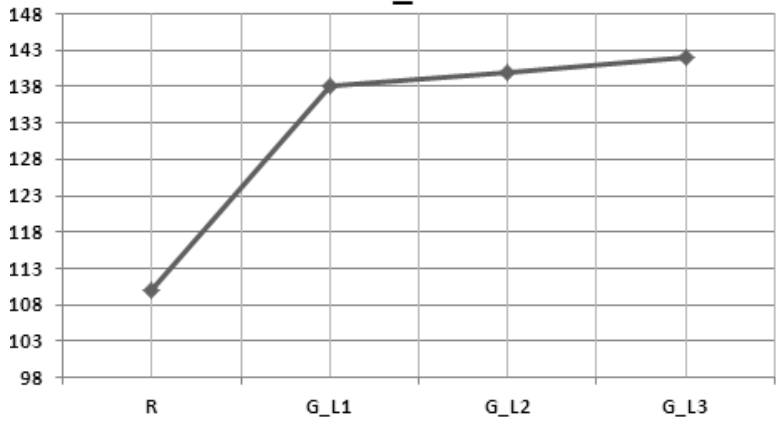

G_L_E

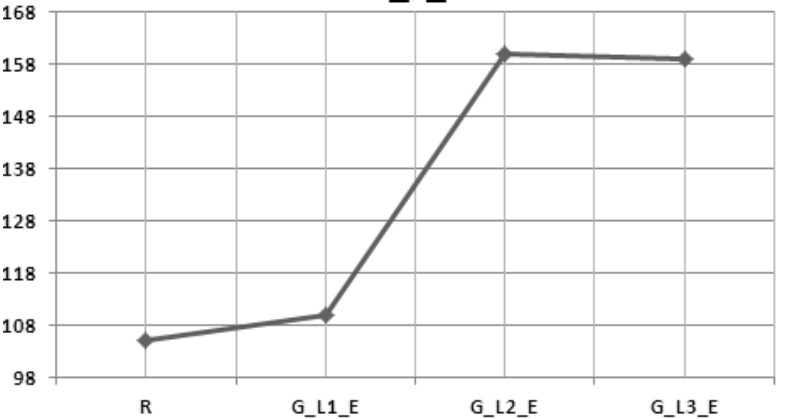

Figure 3. Percentage of increased flexural strength

We compared the computational results mentioned in the directive with laboratorial results. The results indicated a difference in some of the samples, particularly those reinforced by glass fiber. This difference may be explained by the fact that the directive uses carbon fiber rather than glass fiber in flexural strengthening.

As you can see in Figures 1-3, the highest load bearing capacity belongs to three-layer GFRP sample (83KN.m), which means $72 \%$ increase compared to the reference beam. The ultimate creep of this sample is $7.495 \mathrm{~mm}$. The lowest load bearing capacity belongs to single-layer GFRP sample (49.5 KN.m). The highest ductility belongs to three-layer GFRP sample $(11.684 \mathrm{~mm})$ and the lowest ductility belongs to three-layer CFRP sample $(4.14 \mathrm{~mm})$.

The use of CFRP sheets increased the flexural capacity of the beams. The increased number of FRP layers led to the increased flexural capacity ( $15.5 \%$ for one layer, $46.6 \%$ for two layers, and $38.86 \%$ for three layers). As you can see, the increased thickness of layers positively affects the flexural capacity up to a certain point. After a specific limit, the increased thickness does not affect the flexural capacity. The increased flexural capacity depends on the increased number of layers and there is not an optimal value for the number of layers. Also, the increased flexural capacity is accompanied with the reduced ductility of the beams.

No one of the samples underwent FRP failure. In all cases, detachment of concrete cover at the end of FRP system was the main cause of failure, which indicated that the entire capacity of fiber had not been used and that the system had a high tensile capacity. Therefore, if properly used, this system may be a good restorative material. Also, there is not any sign of warning crack in the system, so sufficient care must be exercised when using this system. Moreover, shear failure of the beam under the increased load should be taken into consideration (Figure 4). 

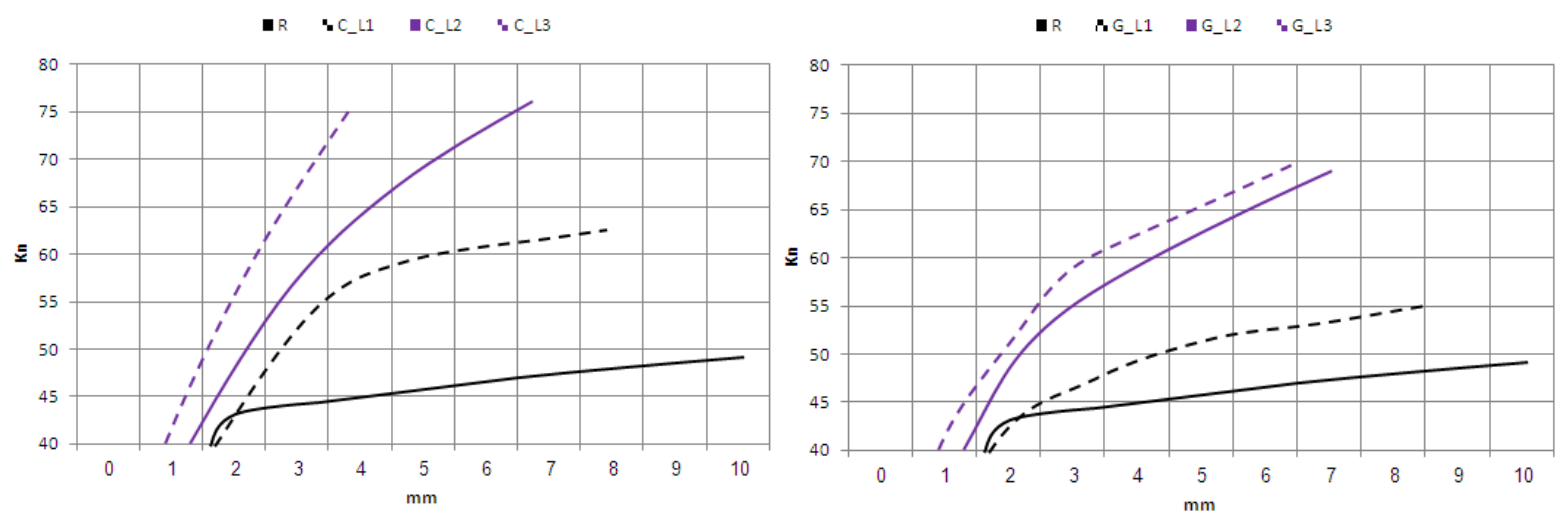

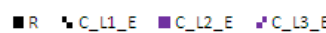
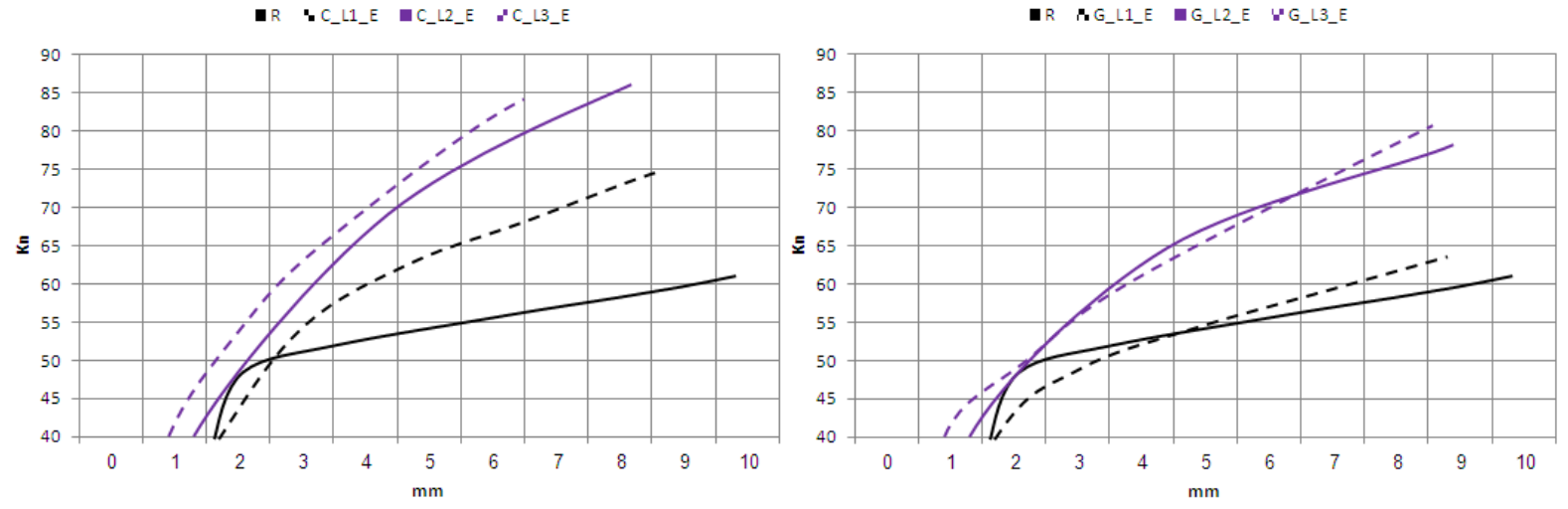

Figure 4. Force-displacement diagram

As you can see in Figure 4, the increased thickness of layers has led to the increased stiffness of the samples. The failure in all four samples was due to lamination at the end of FRP, which is explained by the concentrated stress at the end of fiber.

In CFRP samples, the concurrent existence of FRP sheets in the tensile area of the beam and U-shaped wrap of FRP sheet at the end of tensile area positively affected the flexural behavior and ductility of the beams. FRP wraps prevented the deepening of cracks in shear stress area (Figure 1), as the result of which no lamination occurred at the end of fibers. Therefore, load bearing capacity of the beams increased and the capacity of FRP sheet was optimally used.

In GFRP samples, likewise, the end of FRP sheet was braced by glass fiber, with the only difference that carbon was used instead of glass fiber for the purpose of flexural strengthening. Since glass fiber had higher strain than carbon fiber, GFRP samples had more ductility than CFRP samples. In many cases, the ultimate ductility of GFRP samples even surpassed that of control beam (Figure 1-3).

Since the end of fiber had been braced, load bearing capacity of the samples increased considerably, with three-layer sample having the highest displacement (which even exceeded the reference beam). There was FRP failure in one-layer GFRP samples. In other two samples, detachment of glass fiber and concrete cover was the main cause of failure. In the final steps of loading, the force in tensile part of the beam was borne only by the fiber, with concrete playing no role in practice. Finally, beam failure was due to U brace failure. 


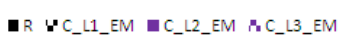

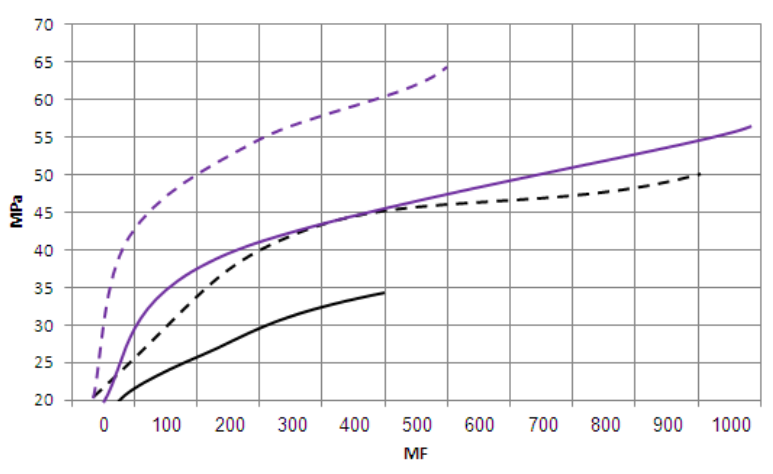

a $R \quad W C_{-} L 1_{-} F F \quad \mid C_{-} L 2_{-} F F \quad W C_{-} L 3_{-} F F$

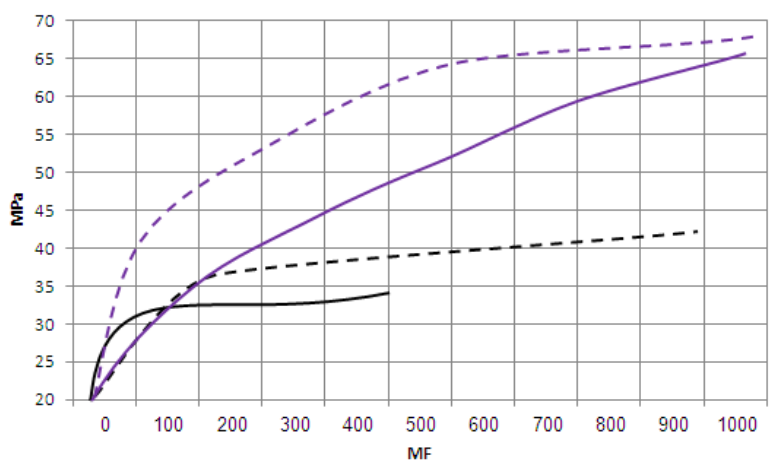

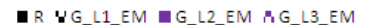

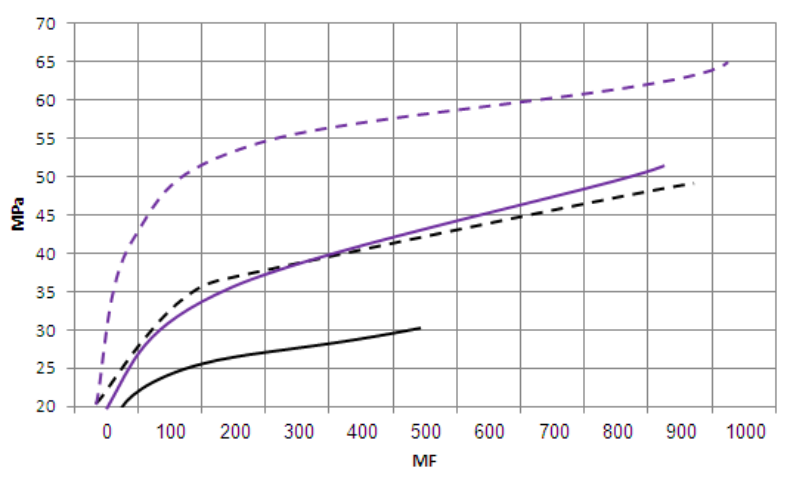

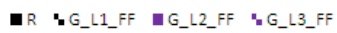

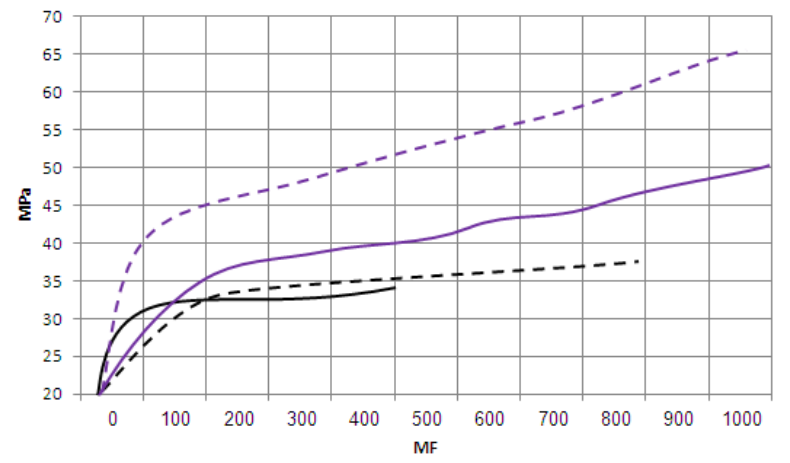

Figure 5. Lateral stress-strain diagram for cylindrical columns
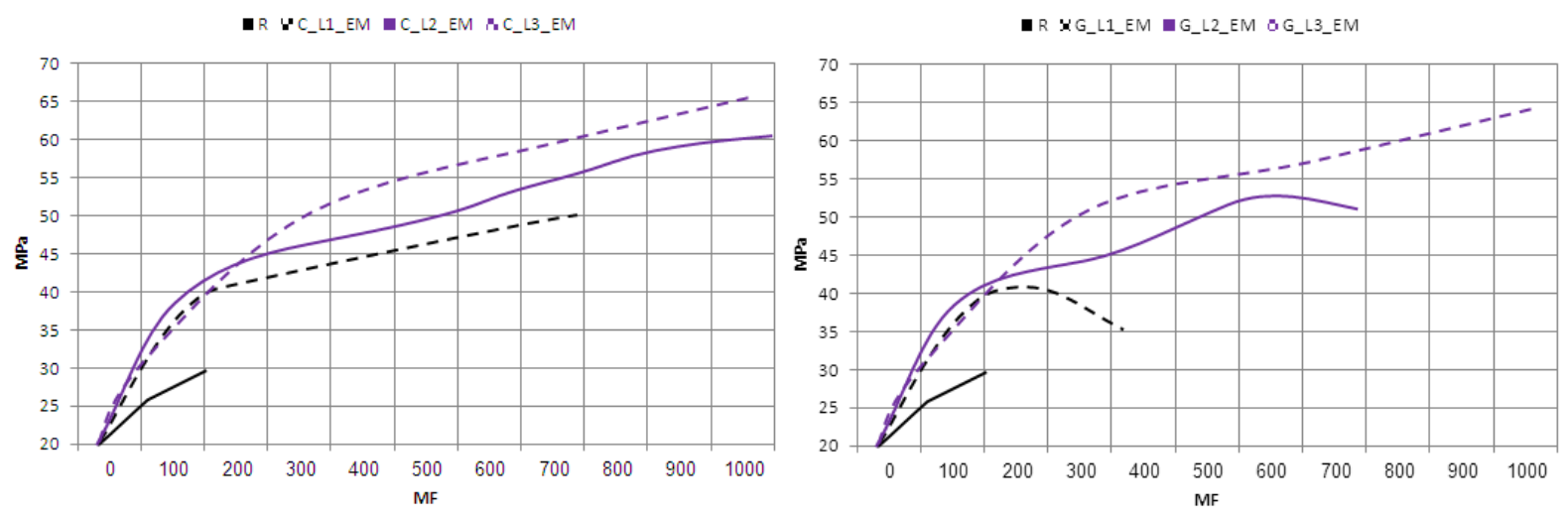

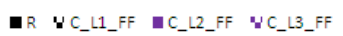

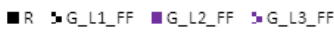
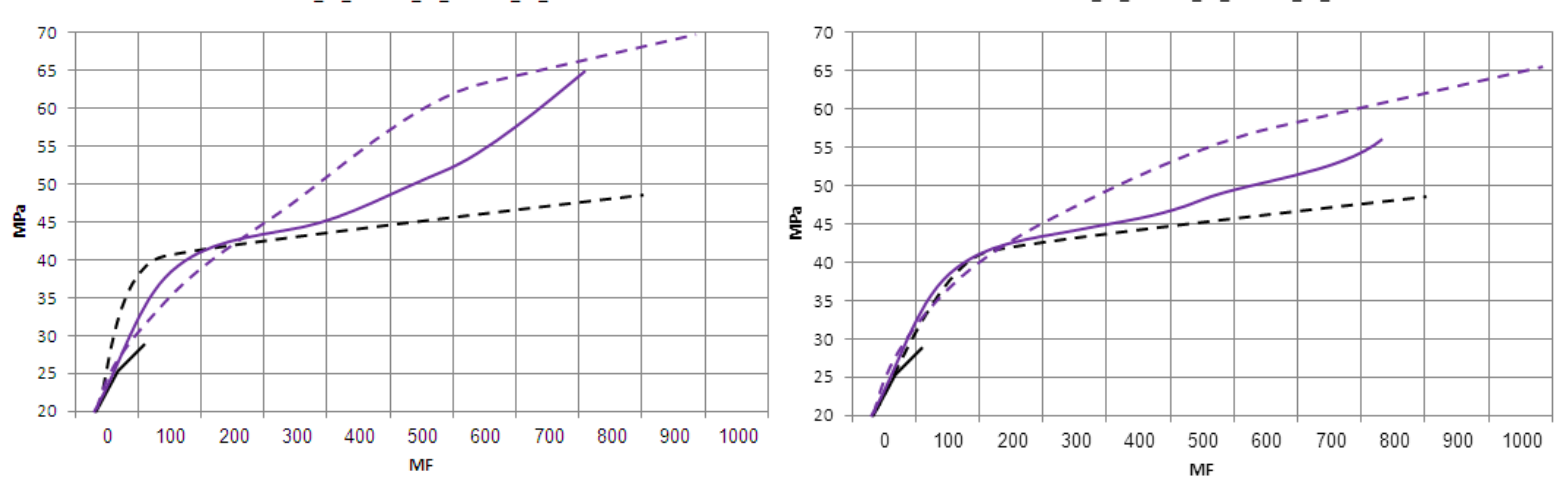

Figure 6. Axial stress-strain diagram for hollow cylindrical columns 
As you can see in Figures 5 and 6, FRP has increased the strength and ductility of all samples. The columns wrapped in CFRP have higher compressive strength, ductility and axial and lateral stiffness compared to GFRP samples. The compressive strength increased by $66 \%$ in one-layer CFRP hollow column, $96 \%$ in two-layer CFRP hollow column, and $123 \%$ in three-layer CFRP hollow column, $36 \%$ in one-layer GFRP hollow column, $63 \%$ in two-layer GFRP hollow column, $105 \%$ in three-layer CFRP hollow column, $71 \%$ in one-layer CFRP filled column, $138 \%$ in two-layer CFRP filled column, $154 \%$ in three-layer CFRP filled columns, $45 \%$ in one-layer GFRP filled column, $79 \%$ in two-layer GFRP filled column, and 144\% in three-layer GFRP filled column.

Generally, fiber wrap had a higher impact on hollow columns than on filled columns. Yet this impact was considerable in hollow columns as well. Moreover, CFRP was more effective than GFRP. The results of flexural-shear strength tests indicated the increased ultimate strength and stiffness of the reinforced beams compared to the reference beam and the reduced ductility of the reinforced beams.

The failure in all of the reinforced beams was of shear type. CFRP beams showed higher ultimate strength but lower ductility compared to other beams. The ultimate strength of the beams with flexural-shear strengthening was higher than other beams. Index 1 means flexural strength and index 2 means flexural-shear strength (Figure 7).
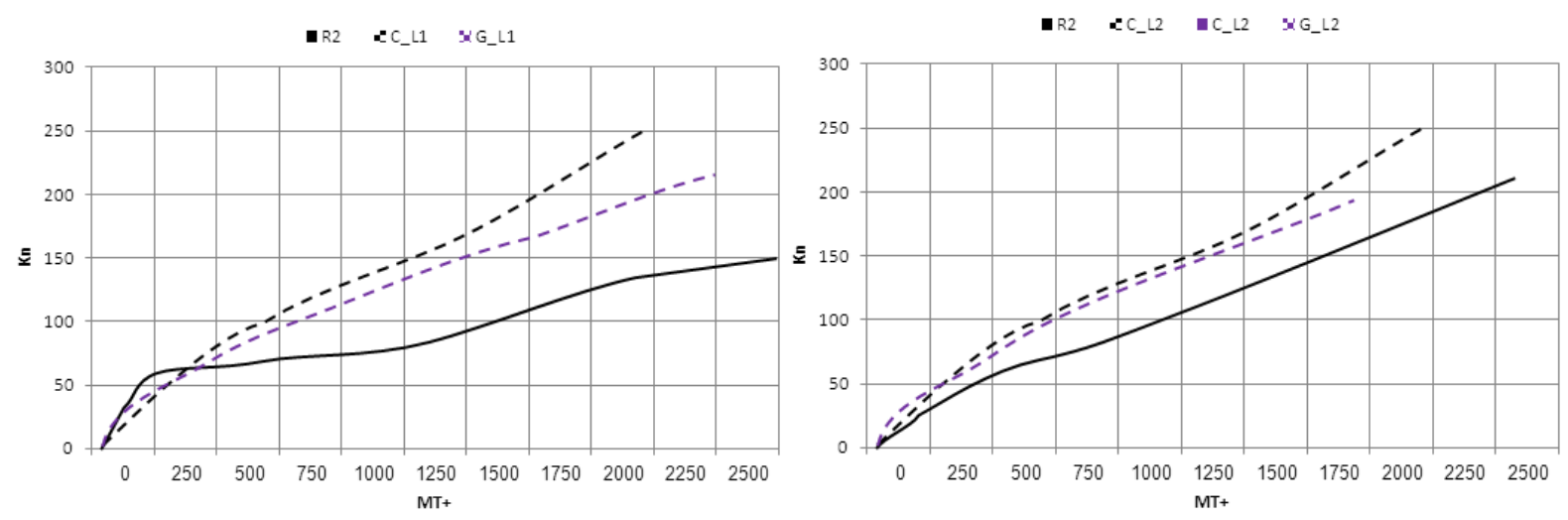

Figure 7. Tensile load-strain diagram

Figure 8 illustrates the results obtained from ultrasonic test after conversion to pulse speed unit $(\mathrm{m} / \mathrm{s})$. As you can see, ultrasonic wave speed has increased in all samples as the result of the increased age. In all ages, the increased fiber has led to the increased speed of the waves passing the concrete. The major part of speed growth occurred in the ages of 3-14 days, followed by a gradual decline in speed growth.
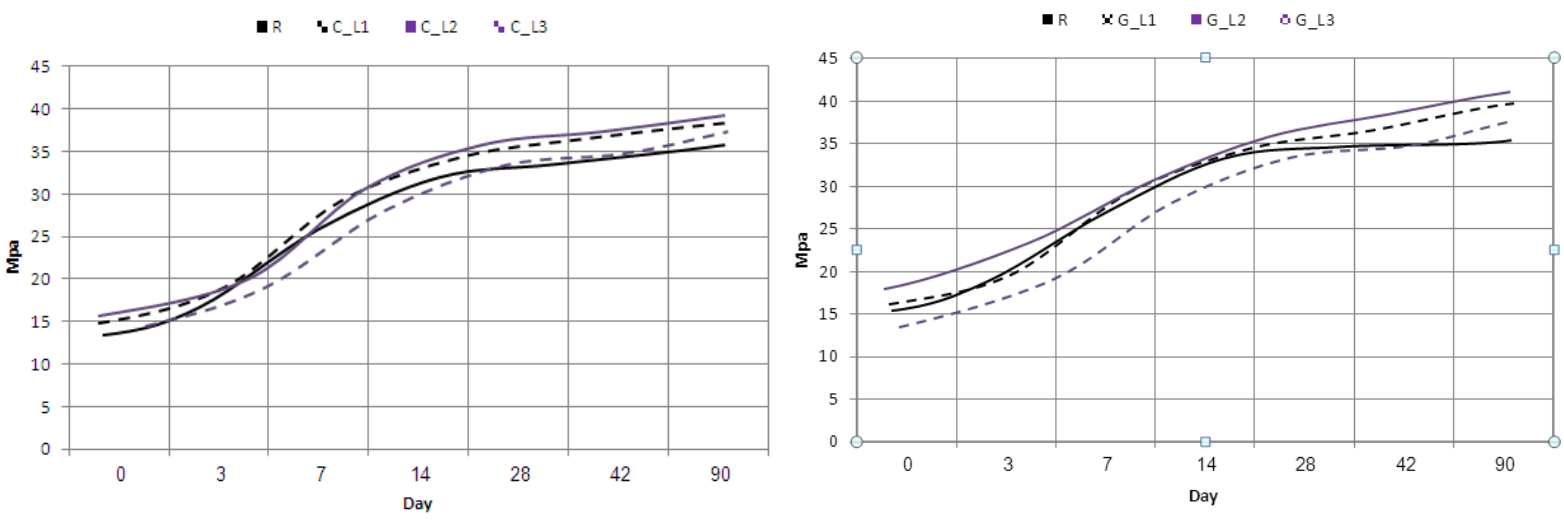

Figure 8. Ultrasonic waves passing the concrete

\section{Conclusion}

FRP method increased the flexural strength of the beams. The samples with FRP sheets and end brace showed a higher load bearing capacity compared to those without a brace. A disadvantage of this system is lamination of layers, which can be prevented by various methods such as fiber brace and electronic brace. The increased thickness of the layers resulted in the increased load bearing capacity of the beams up to a specific limit, so there is an optimal point 
for the thickness of layers. The use of glass fiber increased load bearing capacity and the creep of the beams. In some cases, the creep of the reinforced beams even exceeded the control beam.

In this laboratorial study, we tested 14 hollow and filled columns using concrete mixture with the strength of $20 \mathrm{mpa}$. The results indicated that FRP sheet increased the compressive strength and ductility of the column. Generally, fiber wrap had a higher impact on filled columns than on hollow columns. Yet this impact was considerable in hollow columns as well. Moreover, CFRP was more effective than GFRP.

When the concentrated stress at the end of fiber reached the maximum point, the fiber detached from concrete at the area of tensile reinforcement. To prevent this, the end part of the fiber had to be far enough from the area of tensile reinforcement. This was done by sticking a U-shaped brace at the end of fiber.

In all samples, the increased age resulted in the increased speed of ultrasonic waves. Also, the increased percentage of fiber resulted in the increased speed of ultrasonic waves in all ages compared to control sample. The highest speed growth occurred in the ages of 3-28 days, followed by a gradual decline in speed growth. The highest speed growth in the ages of 3-90 days belonged to G1sample (14\% growth in ultrasonic wave speed). In all samples, the increased compressive strength resulted in the increased speed of ultrasonic waves. The relationship between these two variables was linear.

\section{References}

Abu-Tair, A. I., Lavery, D., Nadjai, A., Rigden, S. R., \& Ahmed, T. M. A. (2000). A new method for evaluating the surface roughness of concrete cut for repair or strengthening. Construction and building materials, 14(3), 171-176. http://dx.doi.org/10.1016/S0950-0618(00)00016-7

Almusallam, T. H., \& Al-Salloum, Y. A. (2005). Use of glass FRP sheets as external flexure reinforcement in RC beams. Department of Civil Engineering, King Saud University, 1.

Antonopoulos, C. P., \& Triantafillou, T. C. (2003). Experimental investigation of FRP-strengthened RC beam-column joints. Journal of composites for construction, 7(1), 39-49. http://dx.doi.org/10.1061/(ASCE)1090-0268(2003)7:1(39)

Arduini, M., \& Nanni, A. (1997). Parametric study of beams with externally bonded FRP reinforcement. ACI Structural Journal, 94(5), 493-501.

ASTM, C. (2005). 1609: Standard Test Method for Flexural Performance of Fiber-Reinforced Concrete (Using Beam With Third-Point Loading). ASTM International, 100.

Attari, N., Amziane, S., \& Chemrouk, M. (2012). Flexural strengthening of concrete beams using CFRP, GFRP and hybrid FRP sheets. Construction and Building Materials, 37, 746-757. http://dx.doi.org/10.1016/j.conbuildmat.2012.07.052

Bakis, C. E., Ganjehlou, A., Kachlakev, D. I., Schupack, M., Balaguru, P. N., Gee, D. J., ... \& Kliger, H. S. (2002). Guide for the design and construction of externally bonded FRP systems for strengthening concrete structures. Reported by ACI Committee, 440.

Barros, J. A., \& Fortes, A. S. (2005). Flexural strengthening of concrete beams with CFRP laminates bonded into $\begin{array}{llll}\text { slits. Cement and } \quad \text { Concrete 27(4), } & \text { Composites, }\end{array}$ http://dx.doi.org/10.1016/j.cemconcomp.2004.07.004

Barros, J. A., \& Sena-Cruz, J. (2002). Bond behavior of carbon laminate strips into concrete by pullout-bending tests. In Bond in concrete: from research to standards: proceedings of the third International Symposium on Bond in Concrete (pp. 614-621).

Belarbi, A. (2011). Design of FRP systems for strengthening concrete girders in shear (Vol. 678). Transportation Research Board.

Belarbi, A., \& Acun, B. (2013). FRP systems in shear strengthening of reinforced concrete structures. Procedia Engineering, 57, 2-8. http://dx.doi.org/10.1016/j.proeng.2013.04.004

Benyoucef, S., Tounsi, A., Bedia, E. A., \& Meftah, S. A. (2007). Creep and shrinkage effect on adhesive stresses in RC beams strengthened with composite laminates. Composites science and technology, 67(6), 933-942. http://dx.doi.org/10.1016/j.compscitech.2006.07.007

Chen, D., \& El-Hacha, R. (2013). Damage tolerance and residual strength of hybrid FRP-UHPC beam. Engineering Structures, 49, 275-283. http://dx.doi.org/10.1016/j.engstruct.2012.11.016

Chen, G. M., Teng, J. G., \& Chen, J. F. (2012). Process of debonding in RC beams shear-strengthened with FRP 
U-strips or side strips. International journal of solids and structures, 49(10), 1266-1282. http://dx.doi.org/10.1016/j.ijsolstr.2012.02.007

Chitsazan, I., Kobraei, M., Jumaat, M. Z., \& Shafigh, P. (2010). An experimental study on the flexural behavior of FRP RC beams and a comparison of the ultimate moment capacity with ACI. Journal of Civil Engineering and Construction Technology, 1(2), 27-42.

Correia, J. R., Branco, F. A., \& Ferreira, J. (2009). GFRP-concrete hybrid cross-sections for floors of buildings. Engineering Structures, 31(6), 1331-1343. http://dx.doi.org/10.1016/j.engstruct.2008.04.021

Correia, J. R., Branco, F. A., \& Ferreira, J. G. (2007). Flexural behaviour of GFRP-concrete hybrid beams with $\begin{array}{lllll}\text { interconnection } & \text { slip. } & \text { Composite } & \text { Structures, } & 77(1),\end{array}$ http://dx.doi.org/10.1016/j.compstruct.2005.06.003

Dalalbashi, A., Eslami, A., \& Ronagh, H. R. (2012). Plastic hinge relocation in RC joints as an alternative method of retrofitting using FRP. Composite Structures, 94(8), 2433-2439. http://dx.doi.org/10.1016/j.compstruct.2012.02.016

El Maaddawy, T., Soudki, K., \& Topper, T. (2005). Long-term performance of corrosion-damaged reinforced concrete beams. ACI Structural Journal, 102(5), 649.

El-Nemr, A., Ahmed, E. A., \& Benmokrane, B. (2013). Flexural behavior and serviceability of normal-and high-strength concrete beams reinforced with glass fiber-reinforced polymer bars. ACI Structural Journal, 110(6), 1077.

Esfahani, M. R., Kianoush, M. R., \& Tajari, A. R. (2007). Flexural behaviour of reinforced concrete beams strengthened by CFRP sheets. Engineering structures, 29(10), 2428-2444. http://dx.doi.org/10.1016/j.engstruct.2006.12.008

Gao, B., Kim, J. K., \& Leung, C. K. (2004). Experimental study on RC beams with FRP strips bonded with rubber modified resins. Composites science and technology, 64(16), 2557-2564. http://dx.doi.org/10.1016/j.compscitech.2004.05.016

Gonilha, J. A., Correia, J. R., \& Branco, F. A. (2014). Structural behaviour of a GFRP-concrete hybrid footbridge prototype: experimental tests and numerical and analytical simulations. Engineering Structures, 60, 11-22. http://dx.doi.org/10.1016/j.engstruct.2013.12.018

Hamid, N. A. A., Thamrin, R., \& Ibrahim, A. (2013). Shear Capacity of Non-Metallic (FRP) Reinforced Concrete Beams with Stirrups. International Journal of Engineering and Technology, 5(5), 593. http://dx.doi.org/10.7763/IJET.2013.V5.624

Hu, H. T., Lin, F. M., \& Jan, Y. Y. (2004). Nonlinear finite element analysis of reinforced concrete beams strengthened by fiber-reinforced plastics. Composite Structures, 63(3), 271-281. http://dx.doi.org/10.1016/S0263-8223(03)00174-0

Kang, T. H. K., Howell, J., Kim, S., \& Lee, D. J. (2012). A state-of-the-art review on debonding failures of FRP laminates externally adhered to concrete. International Journal of Concrete Structures and Materials, 6(2), 123-134. http://dx.doi.org/10.1007/s40069-012-0012-1

Klees, M. (2004). Sachstandsbericht zur Bemessung von Bauteilen mit Klebeverstärkung. TU Kaiserslautern.

Mendes, P. J., Barros, J. A., Sena-Cruz, J. M., \& Taheri, M. (2011). Development of a pedestrian bridge with GFRP profiles and fiber reinforced self-compacting concrete deck. Composite Structures, 93(11), 2969-2982. http://dx.doi.org/10.1016/j.compstruct.2011.05.005

Mutsuyoshi, H., Shiroki, K., Hai, N. D., \& Ishihama, T. (2011). Composite behavior of a pultruded hybrid CFRP-GFRP beam with UFC deck. In Advances in FRP Composites in Civil Engineering (pp. 111-114). Springer Berlin Heidelberg. http://dx.doi.org/10.1007/978-3-642-17487-2_22

Naderi, M. (2011). Using twist-off method for measuring surface strength of concretes cured under different environments. Journal of Materials in Civil Engineering, 23(4), 385-392. http://dx.doi.org/10.1061/(ASCE)MT.1943-5533.0000176

Neagoe, C. A., \& Gil, L. (2014). Evaluation of deflections for PFRP-RC hybrid beams with complete and partial shear connection. In Proceedings of the Second International Conference for Phd Students in Civil Engineering and Architecture: Building the community of young researchers: CE-PhD 2014: Cluj-Napoca-ROMANIA 10-13 December 2014 (pp. 57-64). 
Parikh, K., \& Modhera, C. D. (2012). Application of GFRP on preloaded retrofitted beam for enhancement in flexural strength. International Journal of Civil and Structural Engineering, 2(4), 1070.

Pendhari, S. S., Kant, T., \& Desai, Y. M. (2008). Application of polymer composites in civil construction: A general review. Composite structures, 84(2), 114-124. http://dx.doi.org/10.1016/j.compstruct.2007.06.007

Ronagh, H. R., \& Eslami, A. (2013). Flexural retrofitting of RC buildings using GFRP/CFRP-A comparative study. Composites Part B: Engineering, 46, 188-196. http://dx.doi.org/10.1016/j.compositesb.2012.09.072

Safan, M. A. (2013). Flexural Behavior and Design of Steel-GFRP Reinforced Concrete Beams. ACI Materials Journal, 110(6).

Saraswathy, M. T., \& Dhanalakshmi, M. K. (2014). Investigation of Flexural Behaviour of RCC Beams using GFRP Bars. International Journal of Scientific \& Engineering Research, 5(1), 333-338.

Sekijima, K., Ogisako, E., Miyata, K., \& Hayashi, K. (2001). Analytical study on flexural behavior of GFRP-concrete composite beam. In FRP Composites in Civil Engineering. Proceedings of the International Conference on FRP Composites in Civil Engineering. (No. Volume 2).

Sen, T., \& Reddy, H. J. (2013). Strengthening of RC beams in flexure using natural jute fibre textile reinforced composite system and its comparative study with CFRP and GFRP strengthening systems. International Journal of Sustainable Built Environment, 2(1), 41-55. http://dx.doi.org/10.1016/j.ijsbe.2013.11.001

Seo, S. Y., Feo, L., \& Hui, D. (2013). Bond strength of near surface-mounted FRP plate for retrofit of concrete structures. Composite Structures, 95, 719-727. http://dx.doi.org/10.1016/j.compstruct.2012.08.038

Systèmes, D. (2011). Abaqus, Version 6.11 EF documentation. Rhode Island: Hibbitt, Karlsson \& Sorensen, Inc.

Talbot, C., Pigeon, M., Beaupré, D., \& Morgan, D. R. (1995). Influence of surface preparation on long-term bonding of shotcrete. Materials Journal, 91(6), 560-566.

Tavares, D. H., Giongo, J. S., \& Paultre, P. (2008). Behavior of reinforced concrete beams reinforced with GFRP bars. Revista IBRACON de Estruturas e Materiais, 1(3), 285-295. $\mathrm{http}: / / \mathrm{dx}$. doi.org/10.1590/S1983-41952008000300004

Ueda, T., \& Dai, J. (2005). Interface bond between FRP sheets and concrete substrates: properties, numerical modeling and roles in member behaviour. Progress in Structural Engineering and Materials, 7(1), 27-43. http://dx.doi.org/10.1002/pse.187

Wambold, J. C., Henry, J. J., \& Hegmon, R. R. (1982). Evaluation of pavement surface texture significance and measurement techniques. Wear, 83(2), 351-368. http://dx.doi.org/10.1016/0043-1648(82)90189-2

Yuan, H., Lu, X., Hui, D., \& Feo, L. (2012). Studies on FRP-concrete interface with hardening and softening $\begin{array}{lllll}\text { bond-slip law. } & \text { Composite } & \text { Structures, } & 94(12), & 3781-3792 .\end{array}$ http://dx.doi.org/10.1016/j.compstruct.2012.06.009

\section{Copyrights}

Copyright for this article is retained by the author(s), with first publication rights granted to the journal.

This is an open-access article distributed under the terms and conditions of the Creative Commons Attribution license (http://creativecommons.org/licenses/by/4.0/). 